\title{
LA CONSTITUCIÓN TRADICIONAL Y EL CONSTITUCIONALISMO MEXICANO DE 1824
}

\author{
THE TRADITIONAL CONSTITUTION \\ AND MEXICAN CONSTITUTIONALISM \\ OF 1824
}

\author{
Leopoldo López Valencia \\ El Colegio de Michoacán \\ leopoldo_lopez_valencia@hotmail.com
}

\begin{abstract}
Mexican constitutionalism regarded its earliest political codes as memorable initiatives undertaken by heroic men, though their efforts failed to produce anything more than simple copies of the constitutions of other nations. This initial constitutionalism was, however, constructed upon the ideas of a traditional Constitution previously set forth by the jurist theologians of the Salamancan Neo-Scholasticism. The ideas of sovereignty and federalism applied by the Constituent Assembly of 1824 were not mere copies of other constitutions, but the result of a synthesis of the traditional Constitution and the Enlightenment ideas incorporated into North American and French constitutionalism.
\end{abstract}

Keywords: constitutionalism, tradition, sovereignty, federalism, pactism.

\begin{abstract}
Resumen
El constitucionalismo mexicano consideró sus primeros códigos políticos como memorables intentos, realizados por hombres heroicos, que no lograron ser más que meras copias de otras constituciones. No obstante, ese primer constitucionalismo se construyó con base en ideas de una constitución tradicional expuestas por teólogos juristas de la neoescolástica salmantina. Las ideas de la soberanía y del federalismo utilizadas por el Constituyente de 1824 no fueron simples copias de otras constituciones, sino que resultaron de una síntesis de la propia constitución tradicional y de las ideas ilustradas utilizadas en el constitucionalismo norteamericano y francés.
\end{abstract}

Palabras clave: constitucionalismo, tradición, soberanía, federalismo, pactismo. 


\section{Introducción}

El primer problema al que de modo inevitable se enfrenta una colonia que logra separarse de la metrópoli es el de existir, el de ser, el de darse una vida y una personalidad propias... antes que nada requiere idear la forma como la nueva nación designará a sus autoridades, tarea que antes corría por cuenta de la metrópoli. Y no puede idearse otra forma de hacerlo que mediante una ley superior o suprema, es decir, que esté sobre todas las demás leyes. Por eso se llama "Constitución", porque organiza o constituye al país políticamente. Daniel Cosio Villegas (1998), La Constitución de 1857 y sus críticos.

La aseveración de Cosío Villegas con que se abre este trabajo es una verdad históricamente comprobable, todas las colonias que logran su emancipación entran en el arduo trabajo de constituirse como entidades independientes y soberanas. No obstante, también es cierto que las colonias al emanciparse ya existen, ya son, tienen una vida y una personalidad propias, con o sin una constitución escrita.

La comunidad, aunque libre de una cultura que la identifica de entre todas las sociedades y que le da una determinada cosmovisión; con ella ha heredado un pensamiento que abarcan los fenómenos religioso, político, jurídico, económico, entre otros; esta herencia que la comunidad recibe no se pierde al emanciparse, pues sigue siendo parte de ella y la encuentra en una multitud de instituciones, normas, creencias, en su economía $y$, también, en la forma en la que deben gobernarse y ser gobernados, asimismo, dicha situación va concatenada al reconocimiento y protección de sus derechos, ya sea por medio de jueces o por normas jurídicas. Se hereda, pues, un determinado número de leyes constitucionales o, como también lo podemos llamar, una constitución tradicional.

La herencia hispana que recibió la Nueva España y el México independiente dio los marcos jurídicos necesarios para que la comunidad ordenara su vida cotidiana y sus conflictos, así como la manera en que su conducta trascendería después de su muerte, pues los deudos enfrentarían los procesos relativos a las herencias; quien fallecía enfrentaría el juicio que definiría, mediante sentencia irrecurrible, su destino eterno.

Resulta obvio que Cosío Villegas conocía la dicotomía entre la constitución histórica o tradicional y la constitución legal, entendida ésta como los códigos normativos que los Estados occidentales utilizaron para fijar y sistematizar el derecho público, estableciendo autoridades que gobernarían al pueblo y los derechos connaturales del gobernado.

Los autores de estos códigos políticos, denominados constituyentes originarios, tuvieron facultades soberanas ilimitadas, legalmente hablando, y -en el caso de las colonias emancipadas- al romper política y jurídicamente con sus metrópolis no se encontraban sometidas al orden normativo de éstas: la Constitución, entonces, "es válida porque procede de quien tiene el poder de darla, y es válida incondicionalmente porque ese poder no tiene limitación alguna ya que, en cuanto poder originario, no está sometido a normas" (De Otto, 1995: 53).

El constituyente originario, si bien es cierto que no está sometido a las normas del anterior orden constitucional, con el que ha roto, siempre se encontrará limitado jurídicamente; es éste uno de los puntos en los que el legiscentrismo se queda sin respuestas y se debe acudir al orden jurídico que "vive en la conciencia del pueblo, ya que no es [solamente] un conjunto de reglas abstractas" (Von Savigny, 1878: 30), pues es una realidad histórica (Tomás y Valiente, 1997), una antropología y toda una cultura (Garriga, 2004), que se encuentra plenamente en la conciencia social, de forma muy similar al lenguaje (Von Savigny, 1970).

En síntesis, el constituyente originario se encuentra limitado por la constitución tradicional de la comunidad a la que se le dará un código constitucional' (Beneyto Pérez,

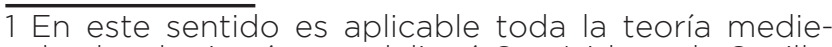
val sobre la tiranía que delineó San Isidoro de Sevilla: "San Isidoro vulgariza allí un texto agustiniano que le llega ya con larga estirpe. Vaya como ejemplo el de Horacio, de una canción en un juego infantil. Los muchachos cantan en el juego: 'Serás rey si obras rectamente'. Cicerón ligaba el príncipe bueno al consejo:
} 
1950: 87-88). “La Constitución legal o escrita ha de respetar la 'Constitución interna' de la nación como cristalización vinculante de su historia, lo que en la práctica política significa que la voluntad constituyente del legislador actual se encuentra limitada por la fidelidad a la Constitución histórica" (Tomás y Valiente, 1996: 31).

Las leyes fundamentales de 1857 y 1917 son, por mucho, los códigos políticos más maduros que ha producido el constitucionalismo mexicano, como lo demuestran los elogios que propios y extraños han hecho de ellos; el primero, por ejemplo, fue calificado como "el edificio constitucional más elaborado y ambicioso que hasta entonces había intentado levantar México", enaltecimiento que compartirían sus autores "porque en su factura intervinieron los hombres más ilustrados, más inteligentes y patriotas con los que el país contaba entonces" (Cosío Villegas, 1998: 16); las alabanzas no se detienen a pesar de que, al poco tiempo de su promulgación, la Constitución fue desobedecida por todos los bandos políticos que luchaban en la Guerra de Reforma,

cónsules porque aconsejan, no reyes porque dominan La máxima sigue creciendo con su segunda parte, en Porfirio, escoliasta de Horacio: Si non facias, non eris. Y Ausonio en su Technopoegnion: Qui recte faciet, non qui dominatur, erit rex. Se va destacando de esa manera una antítesis que cobra en San Isidoro un vuelo excepcional: Regere = recte facere; dominari $=$ non recte facere. Pudiera decirse que se trata de un concepto estereotipado y petrificado para señalar la esencia y el objetivo de la monarquía, para calificar al rey deseable y al príncipe perfecto... La teorización de la monarquía templada, del rey sometido al derecho y cuidado de ejercer el poder con arreglo a normas, es el lugar común de la doctrina isidoriana. Regum a regibus dictum, escribe en las Etimologías. Los reyes - añade- son así llamados porque rigen, como los sacerdotes porque santifican; pero no rige quien no corrige. Por eso los antiguos hicieron el proverbio de que es solamente rey si hace derecho, si no, no. El mismo concepto se repite en las Sentencias. La incorporación del seudo-Cipriano le hace teorizar sobre las virtudes. Dice que dos son las reglas: piedad y justicia. La justicia que el rey ha de aplicar más debe cuidar de los hechos que de las palabras; ir al fondo, es decir, buscar la fundamentación interior y auténtica. Es justo -dice en las Sentencias- moderar las leyes, pero siempre con la reverencia debida a las normas que el propio rey dicta, y a las que -como sus súbditos- ha de estar sometido. El concepto del tirano queda ligado al de rey sin virtudes. Antiguamente, en Grecia y en Roma, no se distinguían entre rey y tirano. Luego -escribe- se llamó tiranos a los malos reyes, es decir, a quienes establecieron un dominio cruel y estaban presos por la lujuria" (Beneyto Pérez, 1950: 87-88). incluso por aquél que peleaba por la conservación y observancia de la Constitución de 1857; tampoco se detienen pese a que durante su vigencia se dio la dictadura de Porfirio Díaz y a que su liberalismo exagerado motivó, entre otras muchas cosas, la Revolución mexicana.

La Constitución de 1917, por su parte, también ha sido enaltecida como la primera en el mundo que reconoció los derechos sociales del hombre, entre otras muchas alabanzas por parte de políticos y constitucionalistas $^{2}$ (Sayeg Helú, 1987: 319); a pesar de que quien conozca la historia del siglo XX mexicano sabrá que durante su vigencia, para los gobernantes, ha sido más sencillo vulnerarla que reformarla y más aún que respetarla, esta Constitución ha sido el culmen de la originalidad mexicana en pos de la protección derechos del hombre, en cuanto individuo y como ente social.

En contraste, las primeras propuestas político-jurídicas que se proyectaron o establecieron durante las primeras décadas del siglo XIX -desde los modelos constitucionales insurgentes hasta las que instauraron una república federal- han sido tachadas de simples copias de las cartas constitucionales europeas o norteamericanas, eso incluso fue motivo de cierto menosprecio hasta por los mismos constituyentes que las elaboraron, situación que en no pocas ocasiones se ha tratado de justificar ${ }^{3}$ (Rabasa, 2005: 349).

2 "Timbre de orgullo es para México su Constitución de 5 de febrero de 1917. En ella se dio cabida, por primera vez sobre la faz de la tierra. Y en conciliante simultaneidad -fuerza es de repetirlo incesantemente-, a derechos individuales y a derechos sociales que, lejos de excluirse, se complementan los unos a los otros. Nuestra Carta de 1917, parece haber captado ya, por completo, la esencia de lo humano, contemplando al hombre en sus dos raíces: la individual y la social" (Sayeg Helú, 1987: 319).

3 "Estrechados por la penuria, agotados por las guerras, sumidos en la anarquía, rodeados por la ignorancia, los constituyentes de 1824 pudieron no haber sido grandes legisladores, pero fueron algo más importante... ifueron grandes patriotas!" (Rabasa, 2005: 349). En cambio, Ernesto de la Torre Villar, en tono menos apologético, pero más mesurado, aseveró que "La Constitución de 1824 revela un grado de desarrollo que la sociedad mexicana tuvo a principios del siglo XIX, un desarrollo no sólo en su organización política, sino general" (De la Torre, 2005: 1). 
Lorenzo de Zavala, por ejemplo, habiendo sido parte del Constituyente, escribió irónicamente que el Acta Constitutiva "apareció a los cuatro meses, como si hubiera sido preciso hacer un gran esfuerzo para copiar artículos de la Constitución española y la de los Estados Unidos del Norte y darles una forma regular y ordenada" (De Zavala, 1950: 29). Lucas Alamán, por su parte, señaló que era una traducción de la Constitución norteamericana y se quejó de que la Constitución de 1824 hizo suyo el sistema electoral y las facultades del congreso y del presidente contemplado en la Constitución gaditana, dando como resultado un "injerto monstruoso de la de Estados Unidos sobre la de Cádiz de 1812" (Alamán, 1885: 589-590).

Este coro secular bien concertado pasó por alto que la tradición jurídico-política de Occidente tendió a desarrollar un modelo constitucional histórico o tradicional, cuyo fin último era la salus animarum, pues "todas las fragilidades, las dudas, las miopías que son connaturales al homo viator tienden a colmarse en un supremo aunque real horizonte que es Dios como verdad" (Grossi, 1996: 153); en esta constitución tradicional la costumbre inveterada es uno de sus principales pilares, como sucede en el common law con su doctrina stare decisis et quieta non movere (Moschzisker, 1924) o en el ius commune, que se desarrolló "bajo una visualización comprensiva y de entendimiento basada, en conexidad escolástica, con el argumentum ad verecundiam o magister dixit", que terminaría siendo la fuente de derecho por excelencia: la "communis opinio doctorum" (Fuentes Contreras y Cárdenas Contreras, 2017: 97-98).

No podía ser diferente si se tiene en consideración que los principales textos de autoridad eran la revelación divina y el Corpus Iuris Civilis, que fue concebido por los juristas 'medievales y los 'bartolistas' de comienzos de la Edad Moderna, como es la ratio scripta, un donum Dei y su actitud ante él fue de sumisión completa, sin espíritu crítico ante los textos que manejaban. Esto lleva a concluir a muchos estudiosos de hoy que la jurisprudencia medieval estuvo dominada por el principio de autoridad..." (Carpintero, 1977; 109).

El mismo derecho natural se fue desarrollando en Occidente con base en el respeto a la autoridad de los autores, ya fueran Dios, San Agustín, Justiniano, Santo Tomás o Bártolo. Es evidente que lo anterior no significa inmovilidad y en ello radicó la importancia de la interpretación de los teólogos y los juristas, quienes con base en la autoridad de los autores interpretaron los textos para dar solución a los problemas y controversias que se daban a lo largo del tiempo.

Este derecho era maleable, especialmente porque no se entendía a la ley como la única fuente de derecho y mucho menos se pensaba en la reducción del fenómeno jurídico a una de sus fuentes: la legislación; al contrario, la estricta aplicación de la ley se entendió como perjudicial e injusta (Stroux, 1926), es por ello que en el Antiguo Régimen, baja Edad Media y la Edad Moderna fueron otras fuentes las que tuvieron supremacía, tales como la costumbre, la doctrina jurídica y, especialmente, las decisiones judiciales. En esa época, especialmente, existía un pluralismo jurídico que obligaba a que el ordenamiento fuera dúctil y, forzosamente, se presentaba en él "discontinuidad y ruptura” (Hespanha, 2002: 25).

Es así como en la tradición jurídica a la que perteneció la Nueva España, y después México, las transformaciones que se dieron se vieron influidas tanto por los legados jurídicos y metajurídicos, como por las tradiciones literarias, las costumbres, los rituales y las ceremonias heredadas del pasado (Hespanha, 2002). España fue parte de esta tradición occidental y desde la Edad Media desarrolló la Ilamada Constitución histórica de su país (Tomás y Valiente, 1997), que habría de ser el substratum de la Carta gaditana de 1812, pues, a pesar de su liberalismo, su proemio es claro al señalar que

las Cortes generales y extraordinarias de la Nación Española bien convencidas, después del más detenido examen y madura deliberación, de que las antiguas leyes fundamentales de esta Monarquía, acompañadas de las 
oportunas providencias y precauciones que aseguren de un modo estable y permanente su entero cumplimiento, podrán llevar debidamente el grande objeto de promover la gloria, la prosperidad y el bien de toda la Nación, decretan la siguiente Constitución política [...] (Constitución política de la Monarquía española, 1820: 2-3).

Además, es claro que encontramos que la legitimación de esta Constitución se hizo con base en argumentos historicistas, como señaló su "Discurso preliminar" (Garriga y Lorente, 2007: 376) pues ahí quedó constancia de que la comisión encargada de extender el proyecto de constitución sentenció que "nada ofrece la Constitución en proyecto que no se halle consignado del modo más auténtico y solmene en los diferentes cuerpos de la legislación española" (Constitución política de la Monarquía española, 1820: 2).

Es por ello por lo que no es extraño que los argumentos de los novohispanos al independizarse de la Monarquía católica apelaran al derecho tradicional, esto de manera similar a la argumentación que se esgrimió a inicio de la época colonial, cuando se discutieron -con base en principios teológicos y jurídicos- los derechos de la Corona sobre las Indias, derechos que sustentaban en los llamados justos títulos. Los argumentos utilizados durante las dos primeras décadas del siglo XIX por los criollos para defender su derecho a la soberanía se sustentaron en argumentos teológicos y jurídicos, como sucedió 300 años antes, en este sentido es posible aseverar que "la historia colonial terminó como había empezado: con una polémica de derecho natural" (Sánchez, 1936: 324-325; Ramos, 1943: 105; Stoetzer, 1979: 193).

\section{Estado de la cuestión}

La Constitución tradicional española, desarrollada durante la Edad Media y apoyada sobre la base de la autoridad de las ideas grecolatinas y del cristianismo, se expandió a los territorios conquistados por la monarquía católica. En el siglo XVI, en el que se consolida la Conquista, se produjo un movimiento intelectual cuya cuna fue la Universidad de Salamanca pero que se expandiría a otras universidades españolas y europeas, especialmente a la de Coímbra; este movimiento sirvió de gozne entre la ciencia medieval, principalmente del tomismo ${ }^{4}$ (Gaos, 1992), con la realidad y necesidades de la Modernidad.

Los teólogos juristas pertenecientes a este movimiento dieron respuesta teórica a las diversas problemáticas a las que se enfrentaron las nacientes monarquías europeas, especialmente con base en un iusnaturalismo católico. Las ideas de estos teólogos juristas tendrían diversos efectos, uno de ellos fue la creación del derecho internacional, con base en el ius gentium que se convertiría con Vitoria en el moderno ius inter gentes, que a la postre daría el paso a una nueva disciplina jurídica, con el granadino Francisco Suárez, "en los últimos capítulos del libro II del De legibus ac Deo legislatore" (García Castillo, 2017: 493).

Los análisis que se han desarrollado sobre la presencia de las ideas de los miembros del movimiento de los teólogos juristas españoles del siglo XVI y XVII se han enfocado en el uso que se le dio a su doctrina iusnaturalista para fundamentar teológica, jurídica y políticamente a los movimientos de independencia de los Estados que surgieron de las posesiones de la monarquía católica en América.

El pionero de estos análisis fue el sevillano Manuel Giménez Fernández, "conocido canonista de la Universidad de Sevilla y experto en historia de la Iglesia en las Indias, sobre lo que realizó numerosas investigaciones" (Petit, 2009). Su obra Las doctrinas populistas en la independencia de Hispanoamérica (Giménez Fernández, 1947) plantea la influencia suareciana en lo que las élites intelectuales criollas y las dirigencias insurgentes entendieron por el origen popular del poder político y la forma en que debía ejercerse, por lo que no tendrían necesidad

4 "La ciencia medieval es eminentemente la asumida y resumida precisamente en las 'sumas', que son un género de obras, de las que la 'maestra' individual es la Suma Teológica de Santo Tomás" (Gaos, 1992; 15). 
de importar estas ideas de culturas ajenas a la española sino bastaría recordar las enseñanzas de las universidades que el despotismo borbónico había intentado proscribir. La idea más trascendental, sin duda, era la que planteaba la reivindicación de la soberanía por la abdicación o deposición de los reyes Borbón.

El autor que más se interesó en esta cuestión durante el siglo XX fue el académico alemán nacido en Argentina $O$. Carlos Stoetzer (1921-2011), quien obtuvo su doctorado en Ciencias Políticas por la Universidad de Georgetown, con su muy discutida y citada disertación The Scholastic Roots of the Spanish American Revolution, publicada en 1979 (Stoetzer, 1979), reimpresa varias veces y traducida al español (Stoetzer, 1982), así como con su obra El pensamiento político en la América española durante el periodo de la emancipación 1789-1825 (Stoetzer, 1966).

Este autor prestó atención a instituciones medievales que se transformaron en el tiempo, tradicionalmente, y en el espacio, como fueron los cabildos municipales que eran sede de la soberanía popular de la escolástica suareciana: poder que el pueblo recibía de forma inmediata de Dios y se trasladaba al rey, en cuya ausencia la soberanía tendría que regresar a los cabildos.

Stoetzer insistió en la presencia del pacto social y la idea medieval de la retroversión de la soberanía en su poseedor original en caso de que se convirtiera en un tirano o desapareciera sin que hubiera sucesor legítimo. En la mentalidad de los insurgentes se unió, entonces, esta idea que pertenecía a su pensamiento tradicional y se hizo una síntesis con las ideas ilustradas francesas y norteamericanas para fundamentar teóricamente las independencias de los Estados hispanoamericanos. Este autor, incluso, analizó la influencia del pensamiento escolástico en la América anglosajona (Stoetzer, 1985), por lo que en cierta forma las influencias de ese país en Latinoamérica tendrían cierto sabor al escolasticismo europeo medieval y moderno.
José Carlos Chiaramonte, de forma más reciente, se ha mostrado cauto en este aspecto pues le parece que no pocos trabajos han poseído "una historia de mal regusto ideológico" (Chiaramonte, 2009: 294); no obstante, los principios jurídicos que configuraron las constituciones contemporáneas fueron los desarrollados por la Escuela iusnaturalista racional, a partir del siglo XVI, cuyos postulados fueron omnipresentes en el lenguaje político-jurídico y social de las nuevas naciones iberoamericanas (Chiaramonte, 2004: 105). La cultura novohispana, entonces, estuvo impregnada de los principios escolásticos medievales y de la Alta Escolástica, por ello es factible argumentar que en los constituyentes de los Estados que surgieron en la América española hubo un discurso ecléctico entre el tradicional derecho natural medieval, Alto Escolástico español y el iusnaturalismo racional de origen protestante.

\section{Fuentes de una misma tradición}

El acta constitutiva de la federación del 31 de enero de 1824 sentó las bases para el establecimiento de un sistema federal y de los estados que lo compondrían; se declaró que la soberanía residía radical y esencialmente en la nación, a la que se le reconoció el derecho de adoptar la forma de gobierno y las leyes fundamentales que le parecieran más convenientes para su conservación y mayor prosperidad; asimismo señaló que el poder supremo de la federación se dividiera en ejecutivo, legislativo y judicial.

El Congreso general constituyente, en ese mismo año, decretó la Constitución federal de los Estados Unidos Mexicanos, que obedeció las directrices del acta constitutiva. Es necesario observar estos documentos como complementarios, como se puede colegir de la lectura del artículo 171 de la Constitución; 5

5 “Art. 171. Jamás se podrán reformar los articulos de esta constitucion y de la acta constitutiva que establecen la libertad é independencia de la nacion mexicana, su religion, forma de gobierno, libertad de imprenta, y division de los poderes supremos de la federación, y de los estados. Dada en México á cuatro del mes de Octubre del año del Señor de mil ochocientos veinte y cuatro: cuarto de la independencia; tercero de la libertad, y segundo de la federación" [Se respeta la 
pues, por ejemplo, la Constitución federal, a diferencia del acta, no hizo referencia a la soberanía, que es un elemento indispensable para constituir a un Estado, ya que no es lo mismo que la soberanía recaiga en Dios, en un monarca, en la nación o en el pueblo.

Los primeros gobiernos del Estado mexicano crearon, paulatinamente, leyes acordes a las ideologías ilustradas y liberales; estas leyes regularon y legitimaron instituciones que ya se intentaba imponer desde las constituciones de Cádiz y Apatzingán. La Constitución federal de 1824 tendía a la instauración de un Estado liberal y nomocrático fundado en la soberanía nacional ${ }^{6}$ que ya ordenaba que el pueblo y el Estado, como estructura de poder, quedaban sometidos a las leyes elaboradas por los representantes del pueblo (Tomás y Valiente, 2001) o, en este caso, de la nación, para ser más específicos.

Los órganos legislativos y judiciales pronto se pronunciaron para declarar vigente al derecho indiano y así estuvo a lo largo de casi todo el siglo XIX, por lo que el derecho propiamente mexicano convivió con el indiano, tanto en sus leyes y doctrina como en sus prácticas jurisdiccionales ${ }^{7}$ (Diego-Fernández Sotelo, 1988), esta situación se replicó en las entidades federativas, por ejemplo, en Michoacán se convocó a un congreso constituyente que se instaló el 6 de

ortografía original del texto consultado] (Constitución Federal de los Estados Unidos Mexicanos, 1824).

6 "Art. 3. La soberanía reside radical y esencialmente en la nación, y por lo mismo pertenece esclusivamente á esta el derecho de adoptar y establecer por medio de sus representantes la forma de gobierno, y demás leyes fundamentales que le parezca mas conveniente para su conservacion y mayor prosperidad, modificándolas ó variándolas, según crea convenirle mas" (Acta Constitutiva de la Federación Mexicana, 1824).

7 "Hoy en día a nadie le cabe la menor duda de que el llamado derecho indiano continuó con vida años después de la consumación de la Independencia en todos los países que habían pertenecido a la Corona española. Ello fue así por el hecho de que los mismos funcionarios, las mismas leyes y los mismos procedimientos seguían en vigor, como no podía ser de otro modo. Tuvo que transcurrir casi un siglo para que esta situación cambiara paulatinamente. Tan vigente seguía el derecho indiano, que a lo largo de la decimonona centuria aparecieron importantes recopilaciones de derecho colonial, como la de Rodríguez de San Miguel, y la de Florentino Mercado" (Diego-Fernández Sotelo, 1988: 139). abril de 1824 (Tena Ramírez, 1968: XIII), esta asamblea constituyente ordenó que ejercieran las facultades judiciales las autoridades que a la fecha lo habían hecho y realizarían dichas funciones con arreglo a las leyes vigentes en ese momento (Coromina, 1886).

El federalismo mexicano instaurado por el acta constitutiva y la Constitución de 1824 no sólo ha sido criticado por ser una -mala-copia del norteamericano, sino que, especialmente, ha sido denostado por ser, supuestamente, ajeno a la realidad mexicana heredada de la Colonia, donde se vivía un centralismo exacerbado, propio de una monarquía absoluta ${ }^{8}$ (Rabasa, 2000). Es evidente que la influencia de la Constitución norteamericana de 1787 está presente en el federalismo mexicano de 1824, pero, en cuanto al legado novohispano, hay que tener cuidado con las generalidades.

En principio debemos considerar que la constitución tradicional hispana, a pesar de estar configurada como una monarquía, estaba limitada jurídicamente por los marcos constitucionales desarrollados de forma histórica, uno de ellos era que el poder estaba fraccionado, por lo que nunca pudo estar concentrado en el monarca.

La sociedad del antiguo régimen fue una comunidad compuesta por colectividades dotadas de cierto grado de jurisdicción, era una sociedad de sociedades (Grossi, 2004: 36), una sociedad de corporaciones dotadas de iurisdictio. Esta idea fue propia del pensamiento occidental y se desarrolló durante la Edad Media, en gran medida en virtud de la idea religiosa del Corpus Christi, pues el pensamiento cristiano, desde la antigüedad, entendió unidas a la Iglesia y a la eucaristía, ambos términos entendidos como el cuerpo místico de Cristo (De Lubac, 2007).

Al respecto, es necesario entender que se consideran tres formas en las que se pre-

8 "El federalismo que se tomó de la Constitución americana significó la antítesis del feroz centralismo de la Colonia, mientras que el establecimiento de la soberanía depositada en la nación implicó el traslado al México independiente, de lo que Ramos Arizpe y otros ilustres constituyentes habían escuchado y aprobado en Cádiz. En breve, la elaboración y aceptación de una constitución escrita fue resolución suficiente para señalar la antítesis a la monarquía absoluta" (Rabasa, 2000: 26-27). 
senta el cuerpo de Cristo: 1. El sentido evangélico, que explica las dos formas en las que se presentó, uno, que se encarnó de María, la virgen, y que se hizo hombre y el otro, que se presenta al transustanciarse, el pan y el vino consagrados. 2. En el Corpus et Sanguinis Christi, mediante el rito sacramental establecido por Jesús en la última cena, donde se establece el rito sacramental de la eucaristía 9 . 3. Aquel cuyo origen procede de las epístolas paulinas ${ }^{10}$, que configuró la idea de que la Iglesia es el Cuerpo de Cristo, conformada por la sociedad de "todos los creyentes pasados, presentes y futuros, reales y potenciales" (Kantorowicz, 2012: 211)"11.

9 Vid. Jn. 1, 14; LC. 22, 19-20. El Credo niceno constantinopolitano también señala la encarnación de Jesucristo: "Et in unum Dominum lesum Christum, Filium Dei unigenitum et ex Patre natum ante omnia saecula, Deum de Deo, Lumen de Lumine, Deum verum de Deo vero, genitum, non factum, consubstantialem Patri: per quem omnia facta sunt: qui propter nos homines et propter nostram salutem, descendit de caelis, et incarnatus est de Spiritu Sancto ex Maria Virgine et homo factus est, ..." (Denzinger y Hünermann, 2017: 381).

10 Algunos ejemplos neotestamentarios de la corporeidad del pueblo cristiano están en Col 1, 24; Rom 12, 4: Col 1, 18: 1 Cor 12-27.

11 Santo Tomás de Aquino es quien resume y potencia esta idea medieval que identifica al Corpus Mysticum con la Iglesia, ya no con el sacramento del altar, el Corpus Christi. El Cuerpo místico de la Iglesia se conforma por todos los hombres que han existido desde el principio hasta el fin de los tiempos. Todos son miembros del Cuerpo místico, unos lo son en acto y otros lo sólo en potencia; de estos últimos, algunos nunca lo serán y otros sí, en algún tiempo, primero por la fe, segundo por la caridad en esta vida y tercero por la gloria en el Cielo. Por ello, Cristo es cabeza de todos los hombres, de todas las épocas, aunque en diverso grado, pues primero lo es de los que están unidos a él en acto por la gloria, luego los que están unidos en acto por la caridad, o sea, por sus obras en este mundo y en tercer lugar los que están unidos en acto por la fe. Después están los que se unen a Cristo sólo potencialmente pero que por la divina predestinación lo serán en acto y por último también es cabeza de los que están unidos en potencia pero que nunca lo serán en acto, ya que no están predestinados a la bienaventuranza celestial, por lo que saliendo de este mundo dejan de ser parte del Corpus mysticum, pues ya no están en potencia de unirse a Cristo. Entre los miembros en potencia se cuentan a los infieles, pues el poder de Cristo es suficiente para salvar a todo el género humano y cuentan con su libre albedrio para ser salvados; también los que viven en pecado mortal son parte del Cuerpo místico, pero sólo potencialmente, no en acto, lo son sólo de forma imperfecta, mediante una fe informe que los une a Cristo de forma relativa, no absoluta. Suma Teológica, IV, q. VIII, a. 3. (De Aquino, 1994: 129-130)
Estas ideas fueron de suma importancia para el desarrollo político jurídico medieval y moderno, pues todo un sistema de imágenes antropomórficas, propias de la teología, fueron utilizadas como base teórica del poder civil.

El gran Cuerpo, entonces, que englobó a la sociedad del antiguo régimen fue la Iglesia católica, pero aunque ésta tuvo y tiene anhelos universalistas no asumió en la Edad Media ínfulas soberanas y, por ende, tampoco tuvo pretensiones de monopolizar la legislatio ni la iurisdictio, como tampoco las tuvieron los reinos germánicos ni los imperios carolingios ni el Sacro Romano Germánico, pues ninguno persiguió el monopolio de la creación y aplicación del derecho; obviamente, hubo una importante legislación y práctica jurisdiccional tanto por el poder público como por las instancias eclesiásticas y el entramado de corporaciones, tales como las universidades, las órdenes religiosas, los ayuntamientos, los señoríos, la nobleza, las cartas pueblas, los fueros municipales y el estamento castrense, todos con jurisdicción y privilegios; además, encontramos las diversas jurisdicciones reales entre las que estaban los alcaldes, corregidores, audiencias y consejos.

En la monarquía católica vemos esa pluralidad de jurisdicciones, de fueros y privilegios. La cabeza misma de la monarquía estaba compuesta por un grupo de consejos reales que trabajaban como tribunales de última instancia y que conformaban el régimen policonsiliar o polisinodial que estuvo plenamente vigente bajo el reinado de los Austrias y que fue perdiendo fuerza bajo el dominio de los Borbón.

Asimismo, es también necesario recordar verdades de Perogrullo para aclarar ese supuesto centralismo que caracterizó a la monarquía hispana, y es que esta monarquía era el conjunto de reinos (Castilla, León, Aragón, Navarra y Portugal) y territorios dotados de autonomía12 que conservaron

12 "... las coronas estaban conformadas por un conjunto de unidades políticas autónomas conocidas con el nombre de reinos y, formando parte de la Corona de Castilla tenemos, aparte de los ya mencionados reinos de Castilla y León que terminaron siendo los principales, otros muchos reinos: Galicia, Asturias, Oviedo, Ex- 
sus derechos e instituciones propias y que rivalizaron con los intentos de recuperar y uniformar a la Hispania visigoda cristiana, a través de la Reconquista y de la imposición de una serie de legislaciones castellanas con pretensiones uniformadoras, en perjuicio de las costumbres locales, principalmente en el ámbito jurídico e institucional pero, pretendiendo, incluso, la uniformidad lingüística.

Estas legislaciones, elaboradas con base en el ius commune fueron, especialmente, el Espéculo y las Siete Partidas, cuya confección pretendía ser una norma de carácter imperial, por el intento de Alfonso X "El Sabio" de ser coronado como emperador del Sacro Imperio Romano germánico. Es bien conocida la mala suerte del Código Alfonsí para ser reconocido como legislación aplicable, ya que al poco tiempo de haberse redactado se desató una protesta generalizada, en 1272, en Castilla, que obligó a Alfonso X a confirmar los fueros antiguos (Wolf, 19931994); incluso, a pesar de que las Siete Partidas adquirieron fuerza legal bajo el reinado de Alfonso XI, bisnieto de El Sabio -al ser incorporadas en el orden de prelación del Ordenamiento de Alcalá- su enorme prestigio e influencia fue más bien como una obra doctrinal, cuyo uso como fuente de derecho llegaría, en los tribunales mexicanos, hasta principios del siglo $\mathrm{XX}^{13}$.

tremadura, Toledo, Sevilla, Granada, Córdoba, y otros más... Como se explica con toda precisión, las posesiones americanas y asiáticas de la monarquía católica se encontraban divididas en grandes unidades territoriales denominadas Audiencias -12 en ese tiempo-, y al interior cada uno de estos territorios autónomos e independientes, se encontraban a su vez organizados en gobernaciones, alcaldías mayores y corregimientos, en la base de los cuales se encontraba una red de ciudades, villas y poblaciones, políticamente organizadas en repúblicas de españoles y repúblicas de indios." (Diego-Fernández Sotelo, 2010: 9, 21-22).

13 "En las Indias se produjo, pues, una recepción de las corrientes jurídicas europeas desde el mismo instante del descubrimiento, pero ella no se limitó al ius commune y a la escuela española del derecho natural, sino que a lo largo del tiempo, se recibió igualmente el influjo del humanismo jurídico, del iusracionalismo, y de la literatura jurídica... La recepción de esta tradición jurídica se verificó por tres grandes vías: una oficial o real, otra académica o científica y otra práctica. Por vía oficial el derecho común romano-canónico se recibió, en cuanto contenido, principalmente a través de las Siete Partidas que, a diferencia de Castilla, se aplica-
Es evidente, pues, que España, tradicionalmente, no fue una entidad exacerbadamente centralizada, al contrario; también podemos considerar que el centralismo que intentó imponerse a la monarquía hispana, bajo el reinado de los Borbón en el siglo XVIII, nunca llego a implantarse, como evidencian los recientes estudios sobre el derecho y las instituciones en este periodo, incluso la historiografía de las llamadas Reformas borbónicas nos muestra la presencia de un poder fraccionado, de carácter pacticio, con una difícil sobrevivencia de los fueros personales (Connaughton, 2015) o territoriales, como es evidente en el Discurso sobre la autoridad de los fueros municipales de Espana, atribuido a Campomanes.

La legislación en el siglo XVIII español:

Aceptada su impronta histórico-moral y jurídica, es posible rastrear las novedades de la ley a la luz de la experiencia dieciochesca, plural y pacticia en su origen, unitaria y reformista en su desarrollo, regalista y nacional en su espíritu, recopilador y casuista al modo antiguo e interpretada internamente por los autores patrios en el siglo de Moser, Montesquieu y Filangieri. Es la nueva ley borbónica que, en rápida síntesis, se reconoce en principio como del rey y del reino al estilo plural austriaco; regalista y patria en el ius publicum posterior, fundamental según la denominación francesa (que sustituye a las sobreleyes o leyes perpetuas de la tradición castellana) o constitucional, referida al régimen político histórico o vigente desde mediados del siglo; humanista e ilustrada con la feliz revolución de Carlos III, extendida a todos los campos; recopilada o simplemente coleccionada en una época que avanza imparablemente hacia la codificación. Esta ley, siguiendo el modelo autocrático impuesto en la Castilla vencida tras las Comunidades, representa ante todo el poder del rey, su ius regale o soberanía, como última manifestación del viejo absolutismo legal bajo la forma de reglamentismo borbónico desde la pragmática, decreto y provisión al humilde ron en Indias preferentemente en materias de derecho privado, supuesta la escasez del derecho municipal y la inexistencia del derecho foral." (Barrientos Grandón, 1993: 11-12). 
bando de gobierno. Pero al tiempo expresa históricamente el poder del reino que sigue concitando el necesario consentimiento en los actos solemnes de los juramentos reales y en las leyes de Cortes que, por vez primera, a salvo las Cortes propias del reino de Navarra, tendrán carácter hispánico. Es una ley que, con la voz del rey, habla el lenguaje consultivo de los Consejos de la monarquía, el reservado de la vía reformista de los Secretarios de Estado y del Despacho o el casuístico de los compiladores que cierran el ciclo legislativo del siglo preparando la Novísima Recopilación en el tiempo nuevo que trabaja con método racionalista el código legal y la Constitución (Coronas, 2010: 184).

En conclusión, la monarquía española no logró ese centralismo del que se le acusa y la Nueva España, como parte de aquélla, tampoco lo lograría incluso en las tan criticadas Reformas borbónicas ${ }^{14}$. Quedémonos, para comprobarlo, con las palabras de León de Arroyal:

La España debemos considerarla compuesta por varias repúblicas confederadas, bajo el gobierno y protección de nuestros reyes. Cada villa la hemos de mirar como un pequeño reino, y todo el reino como una villa grande (De Arroyal, 1789, citado en Fernández, 1992: 239).

Por último, hay que recordar al lector que la Nueva España ciertamente tuvo autoridades centrales, pero también locales, que dividían territorial $\mathrm{y}$, por consecuencia, jurisdiccionalmente a la Nueva España. Esta división obedeció, originalmente y en su mayoría, a las regiones tradicionalmente establecidas en la época prehispánica ${ }^{15}$.

14 Véase para esto las investigaciones que se han producido por los integrantes de la Red de estudios del Régimen de Subdelegaciones en la América borbónica, http://www.rersab.org/

15 "En menos de una década después de la irrupción hispánica, la Corona se adueñó de los territorios, de su población y de sus recursos. Para seguir adelante la conquista y fomentar la colonización, se establecieron las primeras instancias coloniales. Basándose principalmente en los antiguos territorios mexica y mixteca, estudios enfocados en la estructura administrativa novohispana pusieron de manifiesto una cierta conti-
Encontramos entonces que la Nueva España se dividió en reinos, provincias, partidos, gobernaciones, capitanías generales, alcaldías mayores, corregimientos, obispados, dos señoríos, entre otras divisiones territoriales y jurisdiccionales. Además, en virtud de las llamadas Reformas borbónicas, la Nueva España se dividió, en 1786, en intendencias que en gran medida obedecían al territorio de las alcaldías mayores y corregimientos, aunque

debe tomarse en cuenta que para analizar el uso de categorías territoriales en el antiguo régimen fue complejo y poco preciso durante el siglo XVI hasta el siglo XVIII en la América española, incluyendo Nueva España. Un ejemplo significativo fue el de corregimiento, distrito, partido y cabecera. Términos que tenían un carácter jurisdiccional y territorial. Sin embargo, su uso se presta a muchas confusiones al emplearlos indistintamente. Para los especialistas resulta todavía impreciso y es posible que siga siendo un asunto de difícil solución o quizás sea imposible resolverlo y se deba a la propia naturaleza del régimen político imperante durante el período. El asunto tiene importancia, porque a partir de la segunda mitad del siglo XVIII, la política de uniformar y racionalizar el gobierno y la administración territorial supuso homogeneizar las categorías territoriales (De Gortari Rabiela, 2006).

nuidad de las instancias prehispánicas, de su territorio, de sus relaciones con sus pueblos sujetos durante el primer medio siglo de la ocupación hispánica (Lockhart, 1999; Gruzinski, 1991; Terraciano, 2001 y Gibson, 1964). En el territorio tarasco, la estructura del sistema administrativo ha sido abordada por autores como Beltrán (1986, 1994), Navarrete Pellicer (1988), García Alcaraz (1976), Paredes (1998), Pollard (2004) o Carrasco (1986). A partir del análisis de los cinco fragmentos conocidos de la Visita de Caravajal (el documento más antiguo que se refiere al territorio tarasco), Beltrán (1994) explica que se pueden distinguir tres niveles en la pirámide administrativa regional... Durante el primer siglo de la colonia, varias fuentes históricas muestran una permanencia de la organización administrativa prehispánica, Navarrete Pellicer afirma que "la estructura del sistema político administrativo siguió existiendo en una escala más reducida... En todas las jurisdicciones, las cabeceras principales siguieron siendo centros políticos administrativos e incluso asiento de congregaciones de las ordenes mendicantes y clérigos." (Lefebvre, 2020: 209-210). 
Las Intendencias estaban a cargo de un intendente que contaba con el auxilio de un asesor letrado que ejercía la jurisdicción contenciosa civil y criminal, así como cuestiones relacionadas con la Real Hacienda, este asesor también sustituía temporalmente al intendente en caso de enfermedad $u$ otras ausencias. Las intendencias, jurisdiccionalmente, se subdividieron en subdelegaciones; las juntas municipales establecidas en cada villa o lugar de españoles estaban a cargo de un alcalde ordinario (Gutiérrez del Arroyo, 1989). El establecimiento de intendencias dotó de cierta autonomía a los territorios en que se dividió la Nueva España y aumentó con el liberalismo gaditano (Vázquez, 1994).

La Constitución gaditana de 1812 , en su

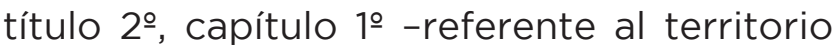
de las Españas- se refiere al territorio español comprendido por la Península y la América septentrional -dividida en Nueva España con la Nueva Galicia y la Península de Yucatán, Guatemala, Provincias internas de Oriente y de Occidente, la isla de Cuba con las dos Floridas- así como a la parte española de la isla de Santo Domingo y la isla de Puerto Rico, con las demás adyacentes a éstas y al continente en uno y otro mar. Es importante señalar que esta Constitución no utiliza la división territorial implantada por la Ordenanza de Intendentes y rescata la idea de las provincias y municipalidades, así como las juntas electorales de parroquia, partido y provincia. El territorio queda divido jurisdiccionalmente en audiencias, en partidos, a cargo de jueces letrados, y en municipios, a cargo de jefes políticos o, en su defecto, de alcaldes.

Para el gobierno de las provincias se estableció el jefe superior y la diputación provincial que, inicialmente, fueron sólo seis: Nueva España, Nueva Galicia, Yucatán, San Luis Potosí, Provincias Internas de Oriente y Provincias Internas de Occidente; en el momento de la independencia de la Nueva España encontramos catorce y al año siguiente, 1822, hubo ya dieciocho con sus respectivas diputaciones provinciales, además de un movimiento inusitado de forma- ción de ayuntamientos con base en el texto gaditano $^{16}$ (Benson, 1992: 31-51).

Este fraccionamiento del territorio y del poder permitió que el Estado mexicano, recién constituido y acéfalo ante la abdicación de Iturbide, echara mano de una de las doctrinas jurídico políticas más añejas y sólidas; me refiero a la tesis de la retroversión de la soberanía en el pueblo. En una entidad extremadamente centralizada, la soberanía hubiera recaído en el Congreso, pero en un Estado como el mexicano, durante sus primeros años, fueron las provincias las que tomaron para sí la soberanía a través de las diputaciones provinciales, la evidencia es que para 1823 muchas de las provincias se habían constituido como estados soberanos ${ }^{17}$, algunos con órganos constituyentes y milicias para proteger su independencia, libertad y soberanía. Lo cierto es que el deseo general de las provincias era seguir unidas pero

16 En 1821 existían las provincias de Nueva Vizcaya, Sonora y Sinaloa, Provincias Internas de Oriente, San Luis Potosí, Zacatecas, Guadalajara, Valladolid, México, Puebla, Veracruz, Oaxaca, Yucatán y Chiapas; en 1822, las Provincias Internas de Oriente se dividieron en Coahuila, Nuevo León, Tejas y Nuevo Santander y se agregaron Querétaro, Tlaxcala y Nuevo México (Benson, 1992: 31-51).

17 Como fue el caso de Jalisco, que a través de la Diputación Provincial de Guadalajara declaró, el 16 de junio de 1823, que se erigía en un estado, soberano y federado: "Que la voluntad de todos los pueblos de la provincia por el sistema de gobierno representativo federado, está manifestada del modo más claro y decisivo: la diputación tiene adoptados los propios sentimientos, y debe conformarse con la voluntad de los pueblos que tiene el honor de representar; y que en consecuencia de esto, y de lo resuelto por esta misma corporación en sus sesiones de 9, 12, 28 y 30 de mayo último y 5 del corriente, declara que es llegado el caso de hacerse el pronunciamiento tan deseado, de erigirse esta Provincia en Estado soberano federado con los demás de la grande Nación Mexicana, con el nombre de Estado Libre de Jalisco" (Vargas Rea, 1958: 17). Incluso, a las pocas semanas, el 14 de septiembre, instaló su Congreso: "ORDEN. Avisando estar constituido e instalado el Congreso constituyente, y nombrados su presidente, vice-presidente y secretarios. Esco. sr. - El Congreso provincial constituyente de este estado libre de Jalisco ha nombrado por su presidente al ciudadano Pedro Vélez, para su vice-presidente al ciudadano Estevan Huerta, y para sus secretarios a los que suscribimos: habiéndose declarado en seguida solemnemente constituido e instalado; y de orden del mismo congreso los participamos a $V$. E. para su debido conocimiento, a fin de que se sirva disponer que se publique. Dios y libertad. Guadalajara 14 de septiembre de 1823" (Congreso del estado de Jalisco, 1826: 1). 
no había uniformidad en la forma en que lo harían, pues, por ejemplo, Jalisco proponía una confederación y Zacatecas, por su parte, una federación.

El Acta Constitutiva (enero de 1824) fundó la Federación Mexicana que volvía a reorganizar el espacio, puesto que creaba nuevos estados. Las doce intendencias y tres gobiernos existentes a la consumación de la independencia se convirtieron en 17 estados y dos territorios. En el curso del debate constitucional, se efectuó otro ajuste. A pesar de que algunos diputados influyentes favorecían la formación de estados grandes, no pudo detenerse la tendencia hacia la fragmentación y la Constitución de 1824 promulgada en octubre reconoció 20 estados, 4 territorios y un Distrito Federal.

Había razones históricas que sustentaban la preferencia federalista y tuvo sus propias características. A pesar de que hubo cierta influencia del federalismo norteamericano hubo diferencias radicales. En el país del norte el gobierno federal gobernaba a ciudadanos; en el mexicano, iba a gobernar estados. En la Convención de Estados Unidos en 1787 que redactó la Constitución ratificada en 1789 no existía desconfianza hacia un centro que no existía y que para todos era necesario. Además, el experimento de la confederación había fracasado, es más, facilitó la constitución de un gobierno federal efectivo, autorizado a cobrar impuestos a los individuos. En México, la tensión entre las regiones y el centro hizo aceptable el unitarismo, pero con un gobierno federal débil (Vázquez, 1994: 107-108).

Es evidente, entonces, que México, al momento de elaborarse el Acta Constitutiva y la Constitución federal, ambas de 1824, contaba con una tradición jurídico-política que no era ajena a un territorio y un poder fraccionado, con corporaciones y territorios autónomos, aunque no independientes.

\section{La soberanía popular. El pacto social en Francisco Suárez}

En cuanto a la soberanía popular, que, como hemos dicho antes, se dice que fue tomada de Cádiz, también es claro que la tradición novohispana la contemplaba desde el medievo y que fue desarrollada por los teólogos juristas españoles, especialmente por Francisco Suárez, como lo podemos ver en diversos ejemplos, uno de ellos es el Plan de Independencia de fray Melchor de Talamantes, sobre todo en su idea del Congreso $\mathrm{Na}$ cional ${ }^{18}$.

Estas ideas estuvieron presentes y fueron bien conocidas en los últimos años de la Nueva España y en los primeros del Estado mexicano. Las élites intelectuales conocían las teorías jurídico-políticas que eran parte de la Constitución histórica española, que, como ya se indicó, fue legada al pueblo novohispano, específicamente a los criollos que fueron quienes alcanzaron la independencia de la metrópoli. Entre estas ideas destacaron - por ser la culminación de la corriente ideológica que sentó las bases del pensamiento político y jurídico de la Modernidad- las que desarrolló y expuso con maestría Francisco Suárez, el último de los grandes teólogos juristas de la Escuela de Salamanca, profesor en varias universidades, entre ellas la de Coímbra, donde escribió sus obras más importantes sobre derecho natural y política, De legibus ac Deo legislatore (1612) y Defensio Fidei Catholicae (1613). Los dirigentes del nuevo Estado conocían las ideas de Suárez, ya fuera a través de la lectura directa de sus obras o a través de las que vulgarizaban su pensamiento. ${ }^{19}$

18 "Careciendo de libertad la metrópoli para ejercer su soberanía y obras expeditamente, oprimida, como se halla, de las tropas francesas, las grandes posesiones de las Américas, parte importante de la nación, deben entrar en posesión de los primitivos y esenciales derechos de aquélla, usando de libres facultades que al presente gozan, para salvar a la patria y no para otro fin. [...] En la $2^{a}$ sesión se declarará a presencia de Dios y de sus santos, la libertad, independencia, soberanía representación, dignidad e integridad de la nación española; reconociendo y declarando, asimismo, que respecto a estar una parte importante de ella impedida para ejercer libremente sus acciones por la opresión de un tirano que intenta dominarla, la América Septentrional Española, como hija primogénita de aquélla, entra en posesión de sus primitivos y esenciales derechos. Declara por consiguiente que toda autoridad naciona debe refundirse en el Congreso [...]" (Talamantes, 1808, citado en De la Torre, 2010: 121-123).

19 Recordemos que la mayoría de los tratadistas del ius naturae et gentium tan utilizados en el siglo XVIII 
El Doctor Eximius, al explicar la fuente del poder político, enseñaba que los gobernantes no recibían la soberanía directamente de Dios, pues éste la entregaba directamente al pueblo y, a su vez, el pueblo encargaba el ejercicio de aquélla al gobernante. Esta idea era parte de la tradición jurídico política occidental y hundía sus raíces en la Antigüedad clásica, como lo expuso el propio Suárez. El derecho romano clásico, recopilado en la obra justinianea, específicamente en el Digesto y en la Instituta, recogía el precepto reconocido como ley regia que aceptaba, según Ulpiano, que el deseo del príncipe tenía fuerza de ley y que la potestad y autoridad de éste le había sido transmitida por el pueblo. ${ }^{20}$

Suárez expone que la ley regia no se llamaba así por emanar de la autoridad de algún rey, sino que recibía tal nombre porque dicha ley trataba sobre el poder del rey y porque explicaba que éste había sido designado como monarca por el pueblo al crear e instituir la dignidad real mediante la traslación de su poder. Esta ley, aclara, no se dio históricamente a través de un solo precepto por medio del cual el pueblo hubiese abdicado del supremo poder de hacer justicia; lo cierto es, según el Eximio, que esta ley se dio a través de un pacto a través del cual el pueblo trasladó al príncipe el poder, con la correlativa carga y obligación de gobernarlo y de administrar justicia. Ese pacto habría logrado que el poder del rey -la lex regiapermaneciera firme y estable.

Este argumento le sirve a Suárez para concluir que el poder de los reyes no viene directamente de Dios, sino que le llega del y aún en el XIX no era de filiación escolástica, no obstante, es clara la influencia del Eximio en varios de sus trabajos, en muchos de ellos ya despojados de su matriz teológica. Sergio Rábade distingue dos líneas en las que influyeron históricamente las ideas de Suárez: una es la línea filosófica alemana, pues en la universidades germanas, católicas y protestantes se estudiaba a Suárez. A partir de ahí se formaron numerosos manuales o resúmenes basados o copiados de la obra del Eximio. La otra línea es la del Racionalismo fundando por Descartes, quien leyó y citó a Suárez en sus obras (Rábade Romeo, 2000: 52 y ss.).

20 "Quod principi placuit, legis habet vigorem: utpote cum lege regia, quae de imperio eius lata est, populus ei et in eum omne suum imperium et potestatem conferat." Dig. 1.4.1pr. pueblo y, para ello, acude a la autoridad del Obispo de Hipona, quien en sus Confesio$n^{21}$

confirma magistralmente esta tesis cuando dice: Pacto General de la sociedad humana es obedecer a sus reyes. Con estas palabras significa que el poder de los reyes y la obediencia que se les debe, tiene su fundamento en un pacto de la sociedad humana, y, por consiguiente, que no tiene su origen en la inmediata institución divina, pues el pacto humano se contrae por voluntad de los hombres (Suárez, 1965: 26).

El Eximio afirma que es erróneo señalar que cuando el poder recae en un solo hombre es en virtud de un acto especial de la voluntad divina, pues no existe en la Revelación esta manifestación de la voluntad de Dios para el conocimiento de los hombres, ni existe en el derecho natural indicio de ello; al contrario, es demostrable que el poder de los reyes no les viene de Dios sino del pueblo y, en caso contrario, no podría hacerse ningún cambio a esta institución. El poder, entonces, Dios se lo ha dado inmediatamente al pueblo, traslación que Dios sanciona y quiere que se respete, por lo que es factible afirmar que Dios les concede a los monarcas su poder de forma mediata porque Dios quiere que se obedezca a los príncipes legítimos (Suárez, 1965: 26-27).

21 "Por otro lado, las ignominias que van en contra de las costumbres humanas deben ser evitadas según la diversidad de costumbres, de modo que el pacto mutuo corroborado por la tradición o la ley de una comunidad o nación no sea quebrantado por el deseo de un ciudadano o un extranjero. Y es que es fea toda parte que no encaja en su conjunto. Por contra, cuando Dios dictamina algo que contradice la costumbre o la convención de cualesquiera, aunque nunca se haya hecho, debe ser hecho; y si hubiese caído en desuso debe ser restaurado; y si no hubiera sido establecido, debe ser establecido. Porque si al rey le está permitido, en el estado que gobierna, ordenar algo que antes de él ni él mismo había ordenado jamás y se le acata sin atentar contra los vínculos de esa comunidad -antes bien es en contra de esos vínculos como no se le acata, en cuanto es convención común de la comunidad humana obedecer a sus reyes- icuánto más hay que someterse sin vacilación a Dios, rector de toda su creación, en todo lo que ordene! Pues al igual que en la jerarquía de la sociedad humana prevalece el poder mayor sobre el menor en cuestión de obediencia, así también Dios sobre todos" (San Agustín, 2010: 202-203). 
En cuanto a la obediencia que se le debe a los reyes, la obligación, en abstracto, es de derecho natural, porque así lo quiere Dios; no obstante, en la práctica, la obediencia y fidelidad a los reyes pertenecen al lus Gentium, esto en razón a que tanto la obediencia como la fidelidad y la misma autoridad regia nacen del pacto que unió a esos hombres en un cuerpo político y en una comunidad perfecta. Por ello, la obediencia civil, en cuanto a su materia y forma de ejercerla, no era igual para todos los hombres que nacen en el reino, esto debido a que el mismo pacto primitivo concedió estas diferencias cuando se celebró entre el monarca y el pueblo; prueba de ello son los fueros y las costumbres; también es claro que el pacto corresponde al derecho de gentes porque el convenio es rescindible o la obediencia y fidelidad no son exigibles cuando el rey intenta someter al pueblo o a alguna persona a cosas ilícitas o que ponen en peligro la salvación del alma (Suárez, 1971: 730).

La retroversión de la soberanía en su original poseedor, el pueblo, es posible, siempre que no haya príncipe legítimo y uno de los casos es que éste deje de serlo al convertirse en un tirano. Suárez, en nombre de los teólogos, afirmó que hay dos tipos de tiranos, uno es el que ocupa el lugar del príncipe por la fuerza y el otro es quien, siendo gobernante legítimo, reina de forma tiránica e injusta, frecuentemente. El rey, como ya se dijo, está sujeto al derecho, a pesar de la ley regia, pues por encima de ella se encuentra el derecho natural que modera su gobierno y le impone reglas para que haga uso de su autoridad de forma justa (Suárez, 1971: 715).

El punto más controvertido de esta tesis es el tiranicidio. Suárez citó a numerosas autoridades, incluso a la petrina, que están en contra de la posibilidad de que un particular pueda dar muerte, justamente, a un príncipe legítimo que se ha tornado en un tirano. Obviamente habla de la doctrina, a la sazón declarada herética, de Wicleff y de Juan Hus, condenada por el Concilio de Constanza.

Explica Suárez que en el caso del tirano, que ocupa por la fuerza el lugar del príncipe, está permitido darle muerte porque en este caso no se está matando al príncipe sino a un enemigo del Estado, situación que Santo Tomás aprobó al alabar a los asesinos de Julio César que ocupaba el poder, no mediante justo título sino mediante la violencia y la tiranía. En este caso, obviamente, no puede haber un crimen de lesa majestad pues el tirano no goza de ninguna majestad. No obstante, este homicidio es ilegítimo en los casos de que alguien ocupe por la fuerza el dominio, jurisdicción o magistratura de un señor que no goza de soberanía y aunque poderoso, éste tiene a un soberano. En este caso, los particulares no le pueden dar muerte de forma legítima, pues al existir un superior, el soberano, no les es lícito tomar las armas contra él ni mucho menos darle muerte, pues los particulares tienen la obligación de recurrir al soberano.

Asimismo, en caso de que no exista un superior al que se pueda acudir para poder darle muerte al usurpador es necesario que la tiranía sea pública, manifiesta y que la muerte del tirano sea absolutamente necesaria para liberar al reino de la tiranía, ya que en caso de que ésta sea dudosa o si existen otros medios menos crueles para liberar al reino, no puede ser lícito darle muerte. Por último, tampoco es lícito darle muerte al tirano si con su muerte se esperan para el Estado los mismos o mayores males o daños, pues siguiendo a Bártolo, asevera que sólo es lícito matar al tirano por el bien común, nunca por el particular. Este caso se daría, por ejemplo, cuando el sucesor del tirano gobernaría también tiránicamente, trayendo iguales o mayores males al Estado (Suárez, 1971: 718-719).

El caso que más le interesaba a Suárez analizar se daba cuando el rey legítimo caía en herejía. Examina lo establecido en el Concilio de Constanza, que condena al que mata a un príncipe tirano por su propia cuenta, sin esperar sentencia o mandato de ningún juez legítimo. Suárez concluye que si un juez legítimo desposeía al tirano de sus derechos como príncipe ya no sería aplicable la definición del Concilio, primero, porque ya no estaríamos frente a un príncipe legítimo y si éste era pertinaz y a través de la violencia 
o fuerza intentaba permanecer en el poder se convertía automáticamente en un tirano; además, se habría cumplido ya el requisito de la sentencia justa y legítima, por lo que el agresor particular no estaría actuando por cuenta propia, pues la sentencia legítima lo convertiría en un instrumento de la autoridad pública (Suárez, 1971: 718-721).

En cuanto incurre en herejía, automáticamente queda de alguna manera privado del dominio y propiedad de su reino, ya que éste, o queda confiscado, o jurídicamente pasa al legítimo sucesor católico; y sin embargo -conforme al capítulo Cum secundum leges-, no se le puede privar del reino sin más, sino que lo posee y administra legítimamente hasta tanto que se le condene mediante sentencia -al menos declaratoria- del delito. En cambio, una vez dada la sentencia, queda privado del reino en absoluto, de suerte que no puede poseerlo con justo título: luego desde ese momento se le podrá tratar como a un perfecto tirano, y consiguientemente cualquier particular podrá matarle (Suárez, 1971: 721).

El problema que surgía inmediatamente era determinar quién podía constituirse en juez del soberano que había tornado en tirano al convertirse en hereje, especialmente porque en el Antiguo régimen el soberano era quien detentaba la suprema iurisdictio de sus reinos. Suárez, con base en la autoridad de doctores de la Iglesia, teólogos y algunos juristas, reconoce dos entes con jurisdicción suficiente para someter al soberano; uno sería el mismo Estado, representado por el común acuerdo de las ciudades y los próceres, a quienes por derecho natural les era lícito rechazar la fuerza con la fuerza y lo segundo, porque el pacto del Estado para transferirle su poder al rey suponía que este caso quedaba exceptuado, pues era necesario para la conservación de éste.

El otro juez legitimo sería el sumo pontífice, quien tenía el poder para aparecer como superior de los reyes, dotado con jurisdicción para corregirlos como sus súbditos en el ámbito espiritual y la herejía era un delito que correspondía precisamente a esa mate- ria. En este caso, el papa podía castigar a los reyes incluso deponiéndolos del trono si era necesario, en virtud de la pertinacia del rey y del bien común de la Iglesia. Ahora bien, en el caso de que el rey incurriera en delitos del orden temporal, también caerían dentro de la jurisdicción del papa, ya que los delitos eran, al mismo tiempo, pecados; así, estas faltas también podían ser corregidas por el poder directo del sumo pontífice y en lo que resultaran nocivas para el Estado podía castigarlas indirectamente, pues el gobierno de un tirano siempre era pernicioso para la salus animarum.

El papa, asimismo, en el caso de un reino cristiano, tenía la potestad de aconsejarle o consentirle que depusiera a un rey que le resultara pernicioso e incluso podía mandarle y forzarle a que lo depusiera cuando fuera necesario para la salvación espiritual del reino, especialmente en los casos que se trataba de impedir que el reino cayera en la herejía o en el cisma y es que en ese caso se justificaba la prevalencia del poder espiritual sobre el temporal, por ello el papa podía, por sí mismo, deponer al rey y, por tanto, también podía forzar al reino a que lo hiciera, pues en caso contrario el poder papal sería ineficaz e insuficiente (Suárez, 1971).

Pues bien, supuesta esta base, sobre el último punto que nos hemos propuesto hay que decir que, una vez que, con poder legítimo, se ha dada condenando al rey a ser privado del reino o -lo que es lo mismo- declarando que ha cometido un delito que lleva consigo tal pena por imposición del derecho, quien ha dado la sentencia o aquel a quien él haya confiado su ejecución puede privar al rey del reino incluso matándole sino puede de otra manera o si la sentencia, siendo justa, alcanza aun a esa pena. Pero al rey depuesto, cualquier persona particular no puede matarle sin más, ni siquiera rechazarle por la fuerza, hasta tanto que se le mande o que en la sentencia misma o en el derecho se haga ese encargo general (Suárez, 1971: 722).

Francisco Suárez, en el mismo sentido que Vitoria, enseñó que la iurisdictio del 
sumo pontífice romano sólo aplicaba para los reinos cristianos, no así para los paganos quienes se podían gobernar con base en la sola prudencia natural. Los paganos y los infieles no bautizados no se encontraban sujetos a la jurisdicción papal; no obstante, los reyes infieles que sí hubieren recibido el bautismo habían quedado sujetos a la plenitudo potestatis del papa, pues el sacramento bautismal deja una marca indeleble, imprime carácter, por lo que a pesar de que cayeran en herejía o apostataren de la Iglesia, llevaban consigo imborrablemente la marca del bautismo, por lo que, aunque ellos quisieran, no podían escapar de la jurisdicción de la Iglesia (Suárez, 1971: 730).

\section{Conclusiones}

El papa León XII, el 24 de septiembre de 1824, emitió el breve Etsi iam diu ${ }^{22}$ para in-

22 Diversos autores al hablar de este documento se refieren a él como una encíclica, cuando lo correcto es, de acuerdo con sus propias características diplomáticas, que dichas letras papales corresponden a la categoría de un breve pontificio (Brading, 1991: 59). Hernández Silva (1990) y varios más la tratan como encíclica, posiblemente siguiendo a Pedro de Leturia, S. I. (1952; 1959), quien estudió con profundidad el documento para probar su autenticidad, así como las causas y el proceso de su elaboración; véase su trabajo "Autenticidad e integridad de la Encíclica del Papa Leon XII sobre la Revolución Hispanoamericana” y su obra Relaciones entre la Santa Sede e Hispanoamérica, T. II, específicamente en su capítulo 13: "La encíclica «Etsi iam diu» del 24 de setiembre de 1824", pp. 241271; ahí, de Leturia, comprueba cómo ese documento realmente obra en los archivos vaticanos y que no es una falsificación ni tampoco fue cierta la tesis de que el documento era espurio o, si no lo era, se aseguraba que algunos párrafos habían sido añadidos, como se afirmó por varios autores, especialmente por Mariano Cuevas que, en por los menos dos de sus obras, apoyo la tesis de que la carta pontificia era falsa o que contenía interpolaciones. En muchas de las citas de la obra de Leturia se refieren al documento como un breve y él mismo afirmó que las diversas redacciones del documento fueron firmadas por el cardenal Albani, Secretario de breves de 1824 (pp. 249-250), incluso muestra un original de este documento pero que fue anulado como se confirma con "la recia tachadura de la firma del cardenal secretario de breves, J. Card. is Albanus" (p. 257). El Pbro. Dr. Luis Medina Ascencio trató al documento como un breve y así lo aclara: "si el Breve (no fué Encíclica) Etsi iam diu salió del Vaticano rumbo a España..." (Medina Ascencio, 1943: 341). Además, los breves pontificios terminan como lo hace éste y otros más de SS León XII: Datum Romae, apud Sanctum Petrum, sub annulo Piscatoris, die 24 Septembris fluir sobre el ánimo de la prelacía americana en favor de Fernando VII, quien aún pretendía recuperar sus posesiones indianas; no obstante, ya eran nuevos vientos los que soplaban en la América hispana y la emancipación de lo que habían sido las Indias occidentales no tendría vuelta atrás.

En México, uno de los que respondieron al llamado pontificio fue José Servando Teresa de Mier, miembro del Constituyente de 1824, diputado por Nuevo León, tanto en el Acta Federativa como en la Constitución federal, quien objetó la potestad pontificia y argumentó que ésta no era absoluta, para ello acudió a las posturas regalistas, tardo-jansenistas, al visigotismo y al conciliarismo que caracterizó al Concilio de Constanza en su sesión VI de 6 de abril de 141523, así como a los cuatro artículos galicanos de 1682, que negaban al papa cualquier jurisdicción sobre las temporalidades de la Iglesia, por ejemplo, la división de las diócesis o el nombramiento de obispos (Saranyana, 2013).

Los intentos de recuperar a la Nueva España sucedieron hasta 1829, con la expedición de Barradas que terminó ese mismo año en la Batalla de Tampico. El 11 de septiembre Isidro Barradas y Antonio López de Santa 1824, Pontificatus nostri anno primo. S. Cardinalis Albanus. Se adecúa, entonces, al quinto periodo dentro de la clasificación temporal en la que se han divido estos documentos pontificios para su estudio; así dentro de dicho quinto periodo (1431-1878) podemos ver el siguiente ejemplo: "Datum Romae apud Sanctum Petrum, sub annulo Piscatoris die $\vee$ Marii, MDLXXXXI, pont. nostri anno primo." (Thurston, 1908).

23 Después de la renuncia de Juan XXIII en la sesión del 2 de marzo de 1415 y de su huida el 20 de marzo, se fortalecieron las tendencias conciliaristas, por lo que el "El 29 de marzo, Viernes Santo, víspera de la cuarta sesión, se redactaron cuatro artículos resueltamente conciliaristas y condenatorios de Juan XXIII. Aun atenuados, no obtuvieron la aprobación en la sesión cuarta (Sábado Santo). Sin embargo, en la turbulenta sesión $\vee$ ( 6 de abril de 1415), con ausencia de la mayoría de los cardenales y con la resistencia de muchos, fue aprobado el decreto <<Sacrosanta >> (6 abril 1415), que contiene los famosos cinco artículos, base del conciliarismo. Estos artículos los renovó sustancialmente el concilio de Basilea, en su sesión 18 (26 de junio de 1434). Más tarde, los abrazó el clero galicano en 1682, y el sínodo de Pistoya (1786). Los artículos del clero galicano fueron desaprobados por Alejandro VIII, en la Constitución Inter multiplices, del 4 de agosto de 1690; los errores del sínodo de Pistoya fueron condenados por Pío VI, en la Constitución Auctorem Fidei, de 28 de agosto de 1794" (Collantes, 1984: 458). 
Anna firmaron la capitulación de las tropas españolas, el festejo incluyó una solemne misa en la basílica de la Virgen de Guadalupe, mito fundante del criollismo protomexicano, nada ajeno a Teresa de Mier.

Fray Servando se enfrentó al deseo de las provincias mexicanas, encabezadas por Jalisco, como ya se dijo antes, que ansiaban una federación que les dotara de una soberanía semejante a la que tenían las antiguas Colonias inglesas, convertidas en los Estados Unidos de América. Y es que, como ha quedado demostrado, las provincias no eran resultado de un división artificial del territorio en entidades federativas, sino que realmente eran regiones que aunque deseaban estar unidas a México también se sabían comunidades autónomas. De acuerdo a la tradición jurídico política propia de los criollos o de las élites regionales mexicanas, querían que se les respetaran esos derechos propios frente al centro, como tradicionalmente se habían hecho con los fueros a las ciudades y corporaciones por parte de los monarcas hispanos; dicha cuestión no era menor, ya que incluso el rey tenía que jurar que los respetaría y cuando era necesario se refrendaba tal juramento.

Las provincias deseaban esa autonomía y la forma que la praxis jurídico-política les ofrecía en ese momento era la que habían adoptado en los Estados Unidos, a pesar de la oposición de personajes de la talla del Padre Mier. Así,

el pensamiento tradicional se unió en una síntesis a las teorías políticas modernas, ya sean inglesas, francesas o norteamericanas, de acuerdo con la idiosincrasia fundamental del genio hispánico, de incorporar otras corrientes ideológicas y amoldarlas a las particularidades del mundo hispánico. El período que culminó en la emancipación de la América española fue en realidad marcado por tal síntesis del pensamiento tradicional con las nuevas ideologías (Stoetzer, 1966: 259).

Adoptar el federalismo era una medida arriesgada pero era la más viable para evitar un fraccionamiento del Estado mexicano, por ello, para conservar la unidad e integridad territorial se adoptó el sistema federal con soberanías locales.

Mier no era un centralista, como se ha pretendido; votó en favor de que apareciera la palabra federación en el Acta Constitutiva en el artículo quinto, que a la postre sería impugnado por él mismo en su discurso que ha sido llamado "las profecías". Fray Servando no estaba en contra del federalismo, sino que intentaba convencer al Constituyente de que México no se encontraba en la situación ideal para llevar a la práctica ese sistema en la forma que lo practicaban los Estados Unidos, por ello precisó que no existía sólo esa forma de federación:

Pero ¿qué no hay más que una forma de federarse? Hay federación en Alemania, la hay en Suiza, la hubo en Holanda, la hay en los Estados Unidos de América, en cada parte ha sido o es diferente, y aún puede haberla de otras varias maneras. Cuál sea la que a nosotros convenga hoc opus, hic labor est. Sobre este objeto va a girar mi discurso. La antigua comisión opinaba, y yo creo todavía, que la federación a los principios debe ser muy compacta, por ser así más análoga a nuestra educación y costumbres y más oportuna para la guerra que nos amaga, hasta que pasadas estas circunstancias en que necesitamos mucha unión, y progresando en la carrera de la libertad, podamos, sin peligro, ir soltando las andaderas de nuestra infancia política hasta llegar al colmo de la perfección social, que tanto nos ha arrebatado la atención en los Estados Unidos. La prosperidad de esa república vecina ha sido, y está siendo el disparador de nuestra América porque no se ha ponderado bastante la inmensa distancia que media entre ellos y nosotros (De Mier, 2016: 622).

¿Qué entendía fray Servando sobre la voluntad general? No era la simple suma de individualidades que se denominaba en ese momento como pueblo; la voluntad general era la que emitían los representantes legítimos del pueblo que debían de deliberar en plena libertad y, en sentido contrario, no podía ser la de la masa general del pueblo 
constituida en su mayoría por hombres groseros e ignorantes (De Mier, 2016: 627).

La democracia en un país como el México de 1823 era, para fray Servando, abrir la puerta a la demagogia, a los excesos y violencia que habían caracterizado a la Francia revolucionaria cuyo pueblo guillotinaba a grandes y sabios hombres, después de que habían sido sus jefes e ídolos. Servando Teresa de Mier pedía que se hiciera una federación, con un centro fuerte, evitando la cláusula que dotaba a las entidades de soberanía, para hacerlas autónomas, pero no soberanas y así estar en condiciones de enfrentar los peligros que él veía más próximos: la división interna, el gobierno arbitrario y sanguinario de las masas incultas y la inminente intervención extranjera.

Fray Servando dejó esta advertencia:

Señor, si tales soberanías se adoptan, si se aprueba el proyecto del acta constitutiva en su totalidad, desde ahora lavo mis manos diciendo como el presidente de Judea, cuando un pueblo tumultante le pidió la muerte de Nuestro Salvador, sin saber lo que se hacía: Inocens ego sum a sanguine justi huyus: Vos videritis. Protestaré que no he tenido parte en los males que van a llover sobre los pueblos del Anáhuac. Los han seducido para que pidan lo que no saben ni entienden, y preveo la división, las emulaciones, el desorden, la ruina y el trastorno de nuestra tierra hasta los cimientos (De Mier, 2016: 639).

Mier deseaba una federación moderada, no un centralismo ${ }^{24}$, pero sí un poder cen-

24 "Otra vez se le ha malinterpretado, y de ahí que en muchos trabajos se lea que fray Servando, al final de su vida, se volvió centralista. Aunque no bastó la explicación en contra, que Mier nos dejó en cuanto a sus más firmes convicciones federalistas, afortunadamente los trabajos de Edmundo O'Gorman, y más recientemente de Andrés Lira, han echado por tierra estas falsas interpretaciones, y han dejado bien claro lo sólido de las convicciones federalistas del diputado por Nuevo León [...] Una cosa era adoptar el modelo republicano y federal que a ellos tan magníficos resultados les dio, y otra ignorar la historia particular de Ios dos pueblos; y si algo distinguió y salvó a Mier fue tener presente la historia. En un tiempo en que lo bien visto era adoptar las modas extranjeras, especialmente las relacionadas con ideas políticas, fray Servando tral fuerte, como el sentido común ordenaría para la situación del país en 1823-1824. Estimaba que la soberanía no tenía que estar en la suma de las individualidades de hombres incultos, sino que aquélla tenía que residir en la voluntad legal de los cuerpos constituidos y de los representantes del electorado más que en el mismo pueblo (Brading, 1991: 94), aunque de éste derivara. Eran, nuevamente, las ideas de los teólogos juristas de la escuela salmantina y la presencia de la sociedad corporativa característica de la constitución tradicional, que era la que más se adaptaba histórica y prácticamente a la sociedad mexicana, que vería el fracaso de su primer federalismo a los pocos años de instaurado, como profetizara fray Servando Teresa de Mier.

\section{Fuentes consultadas}

Acta Constitutiva de la Federación Mexicana (1824), Ciudad de México, Imprenta del Supremo Gobierno en Palacio.

Alamán, Lucas (1885) Historia de México, Tomo $V$, Ciudad de México, Imprenta de Victoriano Agüeros y Comp.

Barrientos Grandón, Javier (1993), La cultura jurídica en la Nueva España, Ciudad de México, Universidad Nacional Autónoma de México.

Beneyto Pérez, Juan (1950), Historia de las doctrinas políticas, Madrid, Aguilar.

Benson, Nettie Lee (1992), The Provincial Deputation in Mexico, Harbinger of Provincial Autonomy, independence and federalism, Austin, University of Texas Press.

Brading, David (1991), Los orígenes del nacionalismo mexicano, Ciudad de México, Era.

se mantuvo siempre fiel a sus raíces históricas, y sólo aceptó de fuera aquello que consideraba compatible y benéfico para el país. Así adoptó la escuela histórica española de la carta magna, pues la pudo traducir perfectamente a la realidad mexicana" (Diego-Fernández Sotelo, 1988: 29-30). 
Carpintero, Francisco (1977), "Mos italicus, mos gallicus y el Humanismo racionalista. Una contribución a la historia de la metodología jurídica", en lus Commune, Frankfurt am Main, Vittorio Klostermann.

Chiaramonte, José Carlos, (2009), "Las dimensiones de las revoluciones por la independencia", Ciencia y Cultura, 2223, La Paz, Universidad Católica Boliviana, pp. 291-299, <https://cutt.ly/cvBIENw>, 13 de enero de 2019.

Chiaramonte, José Carlos (2004), Nación y Estado en Iberoamérica. El lenguaje político en tiempos de independencia, Buenos Aires, Editorial Sudamericana.

Colección de los decretos y órdenes del honorable Congreso constituyente del estado lidre [sic] de Jalisco desde su instalación en 14 de setiembre de 1823 hasta 24 de enero de 1824 que cesó (1826)", Guadalajara, Imprenta de Urbano Sanroman.

Collantes, Justo (1984), La fe de la Iglesia católica. Las ideas y los hombres en los documentos doctrinales del Magisterio, Madrid, Biblioteca de Autores Cristianos.

Connaughton, Brian (2015), "Reforma judicial en España y Nueva España entre los siglos XVIII y XIX: bitácora de agravios, arbitrios procesales y réplica eclesiástica", Estudios de Historia Novohispana, 53, Ciudad de México, Instituto de Investigaciones Históricas/Universidad Nacional Autónoma de México, pp. 30-51.

Constitución Federal de los Estados Unidos Mexicanos (1824), Ciudad de México, Cámara de Diputados.

Constitución Política de la Monarquía Española (1812), Cádiz, Imprenta real.

Coromina, Amador (1886), Recopilación de leyes, decretos y circulares expedidas en el Estado de Michoacán, Tomo I, Morelia, Imprenta de los hijos de I. Arango.

Coronas, Santos (2010), "La ley en la España del siglo XVIII", Anuario de historia del derecho español, núm. 80, Madrid, Departamento de Redacción Boletín Oficial del Estado, pp. 183-242.

Cosío Villegas, Daniel (1998), La Constitución de 1857 y sus críticos, Ciudad de México, Fondo de Cultura Económica.

De Aquino, Tomás (1994), Suma Teológica, Madrid, Biblioteca de Autores Cristianos.

De Gortari Rabiela, Hira (2006), "Nueva España y México: intendencias, modelos constitucionales y categorías territoriales, 1786-1835", Scripta Nova. Revista Electrónica de Geografía y Ciencias Sociales, X (218), <https://bit.ly/3hvQGTF>, 15 de diciembre de 2020.

De la Torre Villar, Ernesto (2005), "La Constitución de 1824", en Diego Valadés y Daniel Armando Barceló Rojas, Examen retrospectivo del sistema constitucional mexicano, Ciudad de México, Instituto de Investigaciones Jurídicas/ Universidad Nacional Autónoma de México.

De la Torre Villar, Ernesto (2010), La Constitución de Apatzingán y los creadores del Estado mexicano, Ciudad de México, Instituto de Investigaciones Históricas/Universidad Nacional Autónoma de México.

De Leturia, Pedro (1952), "Autenticidad e integridad de la Encíclica del Papa Leon XII sobre la Revolución Hispanoamericana", Revista de Historia de América, núm. 34, Ciudad de México, Instituto Panamericano de Geografía e Historia, pp. 413-447.

De Leturia, Pedro (1959), Relaciones entre la Santa Sede e Hispanoamérica, Tomo II, Caracas, Sociedad Bolivariana de Venezuela.

De Lubac, Henry (2007), Corpus Mysticum: The Eucharist and the Church in the Middle Ages: Historical Survey, 2a reimp., traducción de Gemma Simmonds C J, Indiana, University of Notre Dame Press. 
De Mier, Servando Teresa (2016) La Revolución y la Fe: Una antología general, Ciudad de México, Fonde de Cultura Económica-Universidad Nacional Autónoma de México.

De Otto, Ignacio (1995), Derecho constitucional. Sistema de fuentes, Barcelona, Ariel.

De Zavala, Lorenzo (1950), Albores de la república, Empresas Editoriales.

Denzinger, Heinrich y Hünermann, Peter (2017), El magisterio de la Iglesia católica, Barcelona, Herder.

Diego-Fernández Sotelo, Rafael (1988), "La historia de las instituciones novohispanas en el siglo XIX (Alamán, Ramírez, Orozco Y Berra, Icazbalceta)", Cuadernos. Instituto de Investigaciones Juridicas. Ciudad de México, Instituto de Investigaciones Jurídicas/Universidad Nacional Autónoma de México, pp. 139-162.

Diego-Fernández Sotelo, Rafael (1998), "Influencias y evolución del pensamiento político de fray Servando Teresa de Mier", Historia mexicana, 48 (1), Ciudad de México, El Colegio de México, pp. 3-35.

Diego-Fernández Sotelo, Rafael (2010) "De las reales audiencias indianas" en Los caminos de la justicia en México. 18102010, Ciudad de México, Poder Judicial de la Federación, pp. 3-30.

Fernández Albaladejo, Pablo (1992), Fragmentos de Monarquía. Trabajos de historia política, Madrid, Alianza.

Fuentes Contreras, Édgar Hernán. y Cárdenas Contreras, Luz Eliyer (2017), "Genealogía de la asimilación de lo normativo: Análisis del estudio del Derecho en los inicios de las universidades occidentales", Razón Crítica, núm. 3, Bogotá, Universidad de Bogotá Jorge Tadeo Lozano, pp. 85-110.

Gaos, José (1992), Historia de nuestra idea del mundo, Ciudad de México, El Colegio de México-Fondo de Cultura Económica.
García Castillo, Pablo (2017), "El derecho de gentes de Vitoria a Suárez", Disputatio. Boletín de investigación filosófica, 6 (7), Salamanca, Universidad de Salamanca, pp. 489-510.

Garriga, Carlos (2004), "Historia y derecho, historia del derecho", Istor. Revista de Historia Internacional, núm. 16, Ciudad de México, CIDE, pp. 3-8.

Giménez Fernández, Manuel (1947), Las doctrinas populistas en la independencia de Hispanoamérica, Sevilla, Consejo Superior de Investigaciones Científicas-Escuela de estudios Hispanoamericanos de Sevilla.

Grossi, Paolo (2004), "De la sociedad de sociedades a la insularidad del Estado. Entre Edad Media y Edad Moderna", en Paolo Grossi, Derecho, Sociedad, Estado, Ciudad de México, Escuela Libre de Derecho-El Colegio de Michoacán-Universidad Michoacana de San Nicolás de Hidalgo.

Grossi, Paolo (1996), Orden jurídico medieval, Madrid, Marcial Pons.

Gutiérrez del Arroyo, Isabel (1989), "El nuevo régimen institucional bajo la real ordenanza de intendentes de la Nueva España (1786)", Historia Mexicana, 39 (1), Homenaje a Silvio Zavala II, Ciudad de México, El Colegio de México, pp. 89-122.

Hernández Silva, Héctor Cuauhtémoc (1990), "México y la encíclica Etsi iam diu de León XII", Estudios de Historia Moderna y Contemporánea de México, 13 (167), Ciudad de México, Instituto de Investigaciones Históricas/Universidad Nacional Autónoma de México, pp. 81-103.

Hespanha, Antonio Manuel (2002), Cultura juridica europea, Madrid, Tecnos.

Kantorowicz, Ernst Hartwig (2012), Los dos cuerpos del rey. Un estudio de teología política medieval, traducción de Susana Aitón Araluce y Rafael Blázquez Godoy, Madrid, Akal.

Lefebvre, Karine (2020), "Continuidad y transformación de la organización te- 
rritorial en el siglo XVI: el caso de la región de Araró-Zinapécuaro", Relaciones. Estudios de Historia y Sociedad, 41 (162), Zamora, El Colegio de Michoacán, pp. 208-230.

Medina Ascencio, Luis (1943), "Nuevas luces sobre la encíclica de León XIII", Archivium. Revista de la Junta de Historia eclesiástica argentina, T. I, cuaderno 2, julio-diciembre, Alsina, Buenos Aires, pp. 333-363.

Moschzisker, Robert (1924), "Stare decisis in courts of last resort", Harvard Law Review, 37 (4), Harvard, The Harvard Law Review Association, pp. 409-430.

Petit, Carlos (ed.) (2009), "Giménez Fernández, Manuel (1896-1968)", en Diccionario de catedráticos españoles de derecho (1847-1943), Madrid, Instituto Figuerola de Historia y Ciencias Sociales/Universidad Carlos III de Madrid, <https://cutt.ly/qvBgGv1>, 1 de marzo de 2021.

Rábade Romeo, Sergio (2000), Francisco Suárez (1548-1617), Madrid, Ediciones del Orto.

Rabasa, Emilio O. (2005), "La Constitución de 1824: primer acto de autodeterminación mexicana", en Diego Valadés y Daniel Armando Barceló Rojas (coords.), Examen retrospectivo del sistema constitucional mexicano, Ciudad de México, Instituto de Investigaciones Jurídicas/Universidad Nacional Autónoma de México, pp. 345-349.

Rabasa, Emilio O. (2000), Historia de las constituciones mexicanas, Ciudad de México, Instituto de Investigaciones Jurídicas/Universidad Nacional Autónoma de México.

Ramos, Samuel (1943), Historia de la Filosofía en México, Ciudad de México, Imprenta Universitaria.

San Agustín (2010), Confesiones, Madrid, Gredos.

Sánchez Reulet, Aníbal (1936), "Panorama de las ideas filosóficas en Hispanoamé- rica", Letras, 2 (4), Lima, Universidad Nacional Mayor de San Marcos.

Saranyana, Josep-Ignasi (2013), "Presupuestos teológicos de la emancipación mexicana (1767-1830)", lección dictada en el Instituto de Investigaciones Históricas de la UNAM, en la Cátedra extraordinaria Ernesto de la Torre sobre Ideas religiosas en la configuración del imaginario mexicano, 5 de septiembre de 2013, inédito.

Sayeg Helú, Jorge (1987), El constitucionalismo social mexicano, vol. II, Ciudad de México, Universidad Nacional Autónoma de México-Instituto Nacional de Estudios Históricos de la Revolución Mexicana.

Stoetzer, Otto Carlos (1985), "Raíces escolásticas de la Constitución norteamericana", Revista de Historia de América, núm. 99, Ciudad de México, Instituto Panamericano de Geografía e Historia, pp. 157-208.

Stoetzer, Otto Carlos (1982), Las raíces escolásticas de la emancipación de la América española, Madrid, Centro de Estudios Políticos y Constitucionales.

Stoetzer, Otto Carlos (1979), The scholastic roots of the Spanish American Revolution, New York, Fordham University Press.

Stoetzer, Otto Carlos (1966), El pensamiento político en la América española durante el periodo de la emancipación, 17891825, vol. II, Madrid, Instituto de Estudios Políticos.

Stroux, Johannes (1926), Summum Ius Summa iniuria. Ein Kapitel Aus der Geschichte des Interpretatio /uris, Leipzig-Berlín, BG Teubner.

Suárez, Francisco (1971), Defensa de la fe católica y apostólica contra los errores del anglicanismo, Reproducción anastática de la edición príncipe de Coímbra de 1613, vol. IV, Madrid, Instituto de Estudios Políticos. 
Suárez, Francisco (1965), Defensio Fidei III, I, Principatus Politicus o La soberanía popular, Madrid, CSIC.

Tena Ramírez, Felipe, (1968) Michoacán y sus constituciones, Morelia, Ediciones del Gobierno del Estado de Michoacán.

Thurston, H. (1908), "Bulls and briefs", en New advent. Featuring the catholic encyclopedia, New York, Robert Appleton Company, <https://bit.ly/3e4mooR>, 12 de febrero de 2021.

Tomás y Valiente, Francisco (2001), Manual de historia del derecho español, Madrid, Tecnos.

Tomás y Valiente, Francisco (1997), Obras completas, Madrid, Centro de Estudios Políticos y Constitucionales.

Tomás y Valiente, Francisco (1996), Constitución: escritos de introducción histórica, Madrid, Marcial Pons.

Vargas Rea, Luis (1958), Plan de San Luis Potosí y Plan de Jalisco, Ciudad de México, Vargas Rea editor.

Vázquez, Josefina Zoraida (1994), "Reacomodo espacial y político. De la Nueva España a la República mexicana (1786-1824)", Espacio y Desarrol/o, núm. 6, Lima, Fondo Editorial de la Pontificia Universidad Católica del Perú, pp. 93-108.

Von Savigny, Friedrich Karl (1970), "De la vocación de nuestra época para la legislación y la ciencia del Derecho", en Jacques Stern (comp.), La codificación: una controversia programática basada en obras de Thibaut y Savigny, Madrid, Aguilar, pp. 47-169.

Von Savigny, Friedrich Karl (1878), Sistema del Derecho Romano actual, tomo I, Madrid, F. Góngora y Compañía editores.

Wolf, Armin (1993-1994), "Los iura propria en Europa en el siglo XIII", Glossae: European Journal of Legal History, núm. 5-6, Valencia, Instituto de Estudios Sociales, Políticos y Jurídicos/Universidad de Murcia, pp. 35-44.
Recibido: 26 de abril de 2021. Reenviado: 3 de mayo de 2021. Aceptado: 18 de mayo de 2021.

\section{Leopoldo López Valencia}

Es licenciado y maestro en Derecho por la Universidad Michoacana de San Nicolás de Hidalgo, así como maestro y doctor en Ciencias Humanas por el Colegio de Michoacán. Ha cubierto estancias posdoctorales en el Max-Planck-Institut für europäische Rechtsgeschichte (Alemania), en la Escuela de Estudios Hispano-Americanos (España), así como en la UNAM y El Colegio de México. Es miembro del Sistema Nacional de Investigadores (SNI) Nivel I. Sus líneas de investigación son Creencias, Prácticas e Instituciones Religiosas y Cultura y Saberes. Entre sus más recientes publicaciones se encuentran, como autor: De la Constitución Tradicional al Estado de Derecho. La transición jurídica en México, Zamora, El Colegio de Michoacán (2021); "La institucionalización de la jurisdicción judicial en el estado soberano de de Michoacán", en Alejandro Agüero, Andréa Slemian, Rafael Diego-Fernández Sotelo (coords.), Jurisdicciones, Soberanías, Administraciones. Configuración de los espacios políticos en la construcción de los Estados nacionales en Iberoamérica, Zamora, Universidad Nacional de Córdoba/El Colegio de Michoacán, pp. 141-168 (2018), y "La justicia, entre el señorío del juez y el imperio de la ley", en Andrés Lira y Elisa Speckman Guerra (coords.), El mundo del derecho II: Instituciones, justicia y cultura jurídica, Ciudad de México, UNAM-Instituto de Investigaciones Jurídicas/Escuela Libre de Derecho, pp. 313-342 (2017). 